\title{
Laporan Kasus: Amblyomma sp. pada Ular Sanca Kembang (Python reticulatus) di Banyuwangi Reptile Community
}

\author{
Case Report: Amblyomma sp. on Sanca Kembang Snake (Python reticulatus) in \\ Banyuwangi Reptile Community
}

\author{
Wahyu Dwi Katmono ${ }^{1 *}$, Shabrina Fauzia Prayoga ${ }^{1}$, Vivi Oktaviana ${ }^{1}$, Faisal Fikri ${ }^{2}$ \\ ${ }^{1}$ Pendidikan Profesi Dokter Hewan, \\ ${ }^{2}$ Departemen Kedokteran Dasar Veteriner, \\ PSDKU Banyuwangi, Fakultas Kedokteran Hewan, Universitas Airlangga, \\ Jalan Wijaya Kusuma No.113, Mojopanggung, Giri, Banyuwangi \\ *Corresponding author: wahyu.dwi.katmono-2015@fkh.unair.ac.id
}

\begin{abstract}
Abstrak
Sanca kembang (Phyton reticulatus) merupakan reptil yang banyak dipelihara oleh masyarakat. Pemeliharaan Phyton reticulatus banyak diminati karena motif dari kulit dan ular ini mudah beradaptasi. Managemen pemeliharaan yang kurang baik dapat mengakibatkan infestasi caplak yang dapat merusak motif kulit Phyton reticulatus. Phyton reticulatus didapatkan dari Banyuwangi Reptile Community yang dimanfaatkan sebagai hewan peliharaan di Banyuwangi, Jawa Timur. Berdasarkan laporan pemilik, diduga ular ini terinfestasi caplak. Laporan kasus ini bertujuan untuk mendeteksi ektoparasit dari Phyton reticulatus yang dipelihara dan dimanfaatkan dengan tujuan sebagai hewan eksotik. Caplak yang didapatkan dari sanca kembang kemudian dilakukan pemeriksaan menggunakan pembuatan preparat dengan teknik sediaan utuh (whole mount). Berdasarkan hasil pemeriksaan berhasil ditemukan caplak dari genus Amblyomma.
\end{abstract}

Kata kunci: Amblyomma sp., ektoparasit, Phyton reticulatus

\section{Abstract}

Sanca kembang (Python reticulatus) is a reptile which has usually preserve as a pet. It was preserved as a pet due to the color and the ability of adaptation. The poor management could cause tick investations and ruin Pyton reticulatus scale motives. Python reticulatus was obtained from Banyuwangi Reptile Community which is used as a pet in Banyuwangi, East Java. Based on anamnesa the snake was suspected invested by ticks. This case report aims to detect ectoparasites from Pyton reticulatus which preserve as exotic animals. Ticks were examined using preparations with whole mount techniques. Based on the results of the examination, it was found a tick from genus Amblyomma.

Key words: Amblyomma sp., ectoparasite, Phyton reticulatus

Received: 11 April 2019

Revised: 15 Mei 2019

Accepted: 12 Juli 2019

\section{PENDAHULUAN}

Dewasa ini banyak satwa liar terutama ular ditangkap dan dikembangbiakan untuk dijadikan hewan peliharaan. ular dimanfaatkan tidak hanya sebagai sumber bahan baku kerajinan kulit tetapi telah telah dimanfaatkan sebagai hewan peliharaan. Pemeliharaan dan manajemen kesehatan menjadi penting untuk dikembangkan dalam rangka menunjang hobi dalam budidaya ular (Stahlschmidt et al., 2011). Salah satu jenis ular yang sering menjadi binatang peliharaan masyarakat adalah jenis Phyton reticulatus. Ular jenis ini sering menjadi binatang peliharaan karena memiliki pola warna yang menarik, tidak berbisa dan kemampuan adaptasi yang baik dan cara pemeliharaannya cukup mudah (Telnoni, 2016). Beberapa kelompok pecinta reptil memlihara Phyton reticulatus dengan tujuan melestarikannya (Putranto, 2014).

Salah satu masalah dalam pemeliharaan ular adalah adanya parasit pada kulit ular. Parasit pada kulit ular membuat penampilan dari kulit ular tersebut rusak atau berkurang. Ular yang 
dipelihara diindikasikan mengandung parasit dan konsentrasi parasit bisa jauh lebih tinggi daripada ular di alam liar. Ular yang terindikasi parasit dapat menjadi pembawa berbagai penyakit yang di antaranya dapat menginfeksi manusia. Stress merupakan salah satu hal yang mengakibatkan. Efek dari parasit ini dapat memengaruhi semua aspek pemeliharaan reptil. Reptil yang terserang parasit memiliki umur yang lebih pendek, lebih rentan terhadap penyakit lain, meningkatan kematian anak, memperngaruhi pertumbuhan. Parasit pada reptil yaitu protozoa, cacing, dan arthropoda (Klingenberg, 1993). Ektoparasit merupakan permasalahan umum yang merugikan bagi pemilik reptil, namun kurang mendapat perhatian. Kerugian yang ditimbulkan dari ektoparasit adalah penurunan berat badan, anemia, peradangan pada kulit yang dapat menimbulkan abses bahkan berakhir pada kematian (Amanatfard, 2014; Rataj et al., 2011).

Caplak adalah salah satu dari jenis ektoparasit pengisap darah obligat pada vertebrata, terutama mamalia, burung dan reptil di seluruh dunia. Dilaporkan terdapat dua famili, yaitu Ixodidae (caplak keras) dan Argasidae (caplak lunak). Keduanya vektor penting bagi agen patogen yang menyebabkan timbulnya berbagai agen penyakit pada manusia dan hewan di seluruh dunia (Wright, 1985). Indonesia ada sekitar 7 genus caplak keras ditemukan pada ternak dan kebanyakan memiliki peran penting sebagai vektor dan agen penyebab penyakit dan juga memiliki efek merusak pada kulit serta produksi (Anastos, 1950).

Dua famili dari caplak yang paling penting adalah Ixodidae, oleh karena adanya perisai chitinous kaku pada jantan, yang meliputi seluruh permukaan dorsal, tetapi pada betina dewasa, larva, nimfa itu hanya ditemukan pada area terbatas yang memungkinkan abdomen membengkak setelah mengisap darah. Famili Ixodidae meliputi genus Dermacentor, Rhipicephalus, Heamaphysalis, Boophlius, Amblyomma, Hyalomma, dan Aponomma (Ismanto dan Ikawati. 2009). Caplak Amblyomma adalah vektor Aeromonas hydrophilia yang menyebabkan stomatitis bakteri dan pneumonia pada ular (Marcus 1981).

Data mengenai laporan kasus ektoparasit pada Phyton reticulatus untuk wilayah Banyuwangi. Informasi mengenai tentang kasus ektoparasit yang menginfeksi Phyton reticulatus dapat dijadikan data dasar sebagai bahan untuk menentukan pengambilan kebijakan perlakuan medis. Diharapkan data yang diperoleh dapat digunakan untuk melengkapi data kasus ektoparasit pada Phyton reticulatus.

\section{METODE PENELITIAN}

Phyton reticulatus didapatkan dari Banyuwangi Reptile Community. Pemeriksaan dilakukan dengan pemeriksaan fisik dengan melihat dan meraba setiap sisik dari kepala hingga ekor ular. Caplak ditarik dengan pelan menggunakan pinset atau dua ujung jari dari permukaan tubuh inang. Adanya benjolan di bawah sisik ular mengindikasikan adanya manifestasi caplak di bawah sisik. Caplak yang ditemukan selanjutnya disimpan dalam botol kaca berisi alkohol $70 \%$. Pemeriksaan dilakukan di Laboratorium Instrumen Universitas Airlangga PSDKU (Progam Studi Diluar Kampus Utama) Banyuwangi.

Caplak yang telah dikoleksi, selanjutnya dibuat preparat dengan menggunakan teknik whole mount. Pembuatan preparat utuh caplak diawali dengan fiksasi menggunakan alkohol 70\%. Selanjutnya lapisan kitin pada caplak ditipiskan dengan larutan $\mathrm{KOH} 2 \%$ selama 30 menit dan dijernihkan menggunakan xylol. Setelah dehidrasi dengan alkohol bertingkat (30, $50,70,80,95,100 \%$ ) masing - masing 10 menit, selanjutnya caplak direkatkan pada obyek glass dan ditutup dengan cover glass menggunakan entelan.

\section{HASIL DAN PEMBAHASAN}

Phyton reticulatus merupakan ular terpanjang di antara ular jenis lainnya. Phyton reticulatus berukuran besar, tidak berbisa dan memiliki pola lingkaran-lingkaran besar yang berbentuk jala. Pola inilah yang membuat 


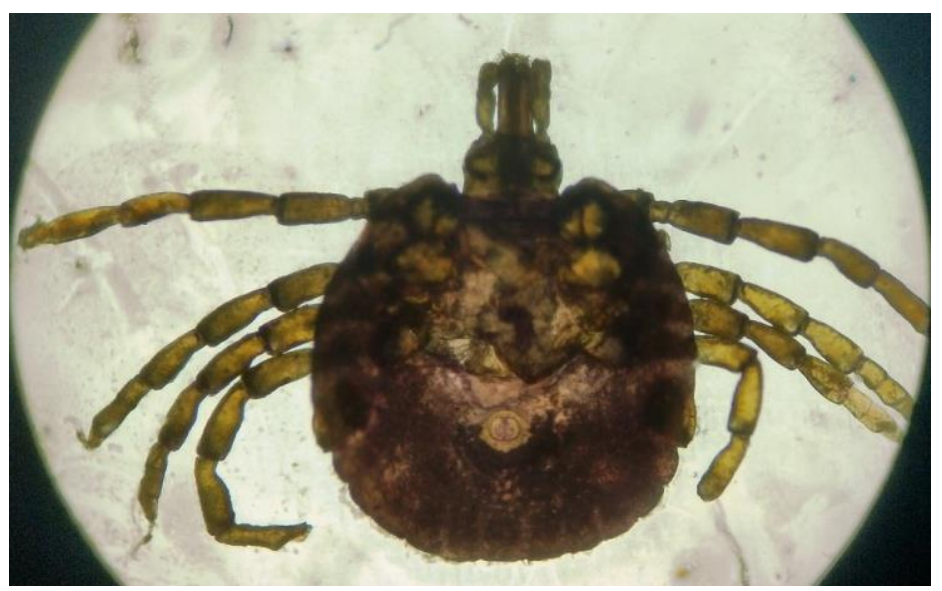

Gambar 1. Caplak Amblyomma sp. pada Phyton reticulatus

masyarakat tertarik untuk menjadikan satwa ini sebagai hewan peliharaan (Rahmayani, 2014). Phyton reticulatus juga memiliki daya adaptasi yang tinggi terhadap lingkungan. Daya adaptasi tersebut yang membuat masyarakat menyukai Phyton reticulatus untuk dijadikan sebagai hewan peliharaan. Berdasarkan data dari IUCN (2018) populasi dari Phyton reticulatus relatif aman dan banyak khususnya wilayah indonesia dan malaysia. Selain dijadikan sebagai hewan peliharaan, Phyton reticulatus juga di buru untuk diambil bagian tubuhnya terutama untuk kulit. Infestasi caplak pada ular dapat mengurangi kualitas dan keindahan pada kulit tersebut.

Berdasarkan pemeriksaan fisik yang dilakukan di Laboratorium Instrumen Universitas Airlangga PSDKU Banyuwangi, dapat disimpulakan bahwa caplak yang didapatkan di tubuh Phyton reticulatus adalah caplak stadium dewasa dari genus Amblyomma (Gambar 1). Berdasarkan ciri umumnya, caplak tersebut dikelompokkan dalam ordo Parasitiformes famili Ixodidae.

Famili Ixodidae memiliki piringan keras pada bagian dorsal sebagai pelindung yang disebut skutum. Pada larva, nimfa, dan caplak dewasa betina, skutum menutupi kira-kira sepertiga bagian dorsal anterior tubuh, sedangkan pada caplak jantan menutupi hampir seluruh bagian dorsal tubuhnya. Bagian skutum memiliki karakteristik yang khas pada setiap genus (Krantz, 1978; Kierans dan Durden 1998; Hadi dan Soviana 2000). Ciri tersebut merupakan ciri pembeda famili Ixodidae dengan famili Argasidae. Caplak Amblyomma $s p$. memiliki ornata (memiliki skutum), memiliki mata dan memiliki palpus panjang. Stadium hidup dari Amblyomma sp. adalah larva, nimfa dan stadium dewasa. Pada stadium dewasa, Amblyomma sp. akan menempel pada tubuh induk semang kemudian jatuh untuk bertelur kembali (Levine, 1990).

Berdasarkan morfologi caplak yang ditemukan pada penelitian ini, dapat diketahui bahwa caplak tersebut adalah caplak spesies Amblyomma helvolum. Menurut Tanskul et al., (1983), spesies caplak ini banyak ditemukan pada ular Phyton khususnya pada Phyton reticulatus. Caplak Amblyomma helvolum di Indonesia tersebar di Sumatera, Jawa, Kalimantan, Sulawesi, Pulau Komodo, Flores, dan Tanimbar (Kolonin, 2009). Amblyomma helvolum memiliki punggung dorsal dengan capituli berbentuk oval. Skutum bentuk dalam dan datar, mata berbentuk elips. Hipostom berbentuk memanjang dengan banyak gigi tajam (3/3). Organ genital pada betina terletak pada coxae II dan III. Adanya makula besar dan berisi pada ventral tubuh, anal berbentuk melengkung dan terletak di posterior anus (Robbins,1996; Norval et al., 2009).

Infestasi parasit caplak relatif tidak berbahaya, namun dapat menjadi lebih parah dan bahkan bisa menyebabkan kematian jika sistem imunitas tubuh inang terganggu. Kematian dan penurunan imunitas tubuh disebabkan karena menurun asupan makanan yang disebabkan oleh anemia, dermatitis, dan infestasi parasit yang berat (Cooper, 2001; Mader, 2006). Gejala klinis yang tampak pada kulit ular yang terinfeksi 
caplak Amblyomma helvolum adalah adanya lesi pada kulit. Lesi tersebut berupa kerusakan jaringan, abses dan dysecdysis. Infestasi caplak merupakan penyebab utama kerusakan epidermal kulit (Catherine et al., 2017). Dampak lain dari infestasi ektoparasit caplak adalah kekurangan darah (anemia), kerusakan kulit atau iritasi dan alergi. Kerusakan kulit tersebut mengakibatkan hewan menyakiti diri sendiri atau self wounding pada bagian tubuh yang terasa gatal akibat ektoparasit (Wall and Shearer 2001). Menurut Widiastuti (2008) Caplak memiliki chelicerae atau semacam gigi yang digunakan untuk merobek kulit inangnya dan memasukkan mulutnya. Hypostome pada bagian mulut caplak akan mengaitkan caplak di tubuh inangnya. Darah inang dipompa oleh muscular pharynx. kelenjar saliva caplak akan memproduksi suatu anti koagulan yang akan mencegah darah inang terkoagulasi selama caplak menghisap darah.

Caplak juga dapat memproduksi racun atau substansi toksik, serta berperan sebagai inang antara untuk protozoa dan helminth. Caplak juga berperan sebagai vektor bagi bakteri, virus, Spirochaeta, Ricketsia, Chlamydia, dan agen penyakit lainnya (Hendrix, 2012). Genus Amblyomma merupakan vektor utama dari penyakit Tularemia dan Rocky Mountain spotted fever (tick borne thypus fever). Caplak juga berperan dalam penyebaran penyakit lain seperti seperti Far-eastern spring summer, encephalitis, Tick-borne encephalitis, Boutonneuse fever, African tick fever, Queensland tick typhus, Russian tick typhus, dan Q-fever (Ismanto dan Ikawati, 2009).

\section{KESIMPULAN}

Studi kasus ini mengidentifikasi caplak Phyton reticulatus yang ditemukan adalah genus dari Amblyomma.

\section{UCAPAN TERIMA KASIH}

Peneliti mengucapkan terimakasih kepada Banyuwangi reptil community yang telah bekerjasama sehingga penelitian dapat dilaksanakan dengan baik.

\section{DAFTAR PUSTAKA}

Amanatfard. 2014. Human Dermatitis Caused by Ophionyssus natricis, a Snake Mite. J. Iranian J. Parasitol., 9(4), 594-596.

Catherine, B.R., Jayathangaraj, M.G., Soundararajan, C., Yoaraj, D., Bala Guru, C. 2017. Skin Affections due to Amblyomma gervaisi Ticks on Snakes.

Cooper, J.E. 2001. Host-parasite relations in reptiles and amphibians, ARAV Proceedings Eighth Annual Conference.

Hadi, U.K., Soviana, S. 2000. Ektoparasit: Pengenalan, Diagnosa, dan Pengendalian. Bogor: Institut Pertanian Bogor.

Hendrix, C. 2012. Diagnostic Parasitology for Veterinary Technician. USA: Elsevier Mosby.

Ismanto, H., Ikawati, B. 2009. Caplak Keras (Hard ticks) Sebagai Vektor Penyakit. BALABA: Jurnal Litbang Pengendalian Penyakit Bersumber Binatang Banjarnegara, p22-23.

Kierans, J.E., Durden, L.E. 1998. Illustrated Key to Nymph of the Tick Genus Amblyomma (Acari: Ixodidae) Found in United States. J. Med. Entomol., 35(4), 489495.

Klingenberg, R.J. 1993. Understanding Reptile Parasites. The Herpetocultural Library Series. BowTie Press, Irvine, California. $\mathrm{p}$ 44-45.

Kolonin, G.V. 2009. Fauna of Ixodid ticks of the world. www.kolonin.org.

Krantz, G.W. 1978. A Manual of Acarology. Corvallis, Oregon: Oregon State University Book Stores Inc. 
Levine, N.D. 1990. Buku pelajaran parasitologi veteriner. Gajah Mada University Press.Yogyakarta.

Mader, D.R. 2006. Reptile Medicine and Surgery, 2nd Edn. Saunders Elsevier, St. Louis, Missouri. p1124.

Manurung, J. 2002. Studi prevalensi infeksi caplak pada sapi di Kecamatan Ciracap dan Kecamatan Surade Kabupaten Sukabumi Jawa Barat dan cara-cara peternak menanggulanginya. Seminar Nasional Teknologi Peternakan dan Veteriner.

Marcus, L.C. 1981. Veterinary biology and medicine of captive amphibians and reptiles. Lea and Febiger, Philadelphia, PA.

Norval, G., Robbins, R.G., Kolonin, G., Shiao, P.J., Mao, J.J. 2009. Unintentional trans-port of ticks into Taiwan on a king cobra (Ophiophagus hannah). Herpetol., 2, 203206.

Putranto, D. 2014. Keanekaragaman Reptil Impor Di Yogyakarta. [Skripsi]. Fakultas Teknobiologi Universitas Atma Jaya Yogyakarta: Yogyakarta.

Rahmayani. 2014. Infeksi Cacing Saluran Pencernaan Ular Sanca (Python Reticulatus Schneider 1810) Sebagai Exotic Pets [Skripsi]. Fakultas Kedokteran Hewan Institut Pertanian Bogor, Bogor.

Ramadhan, R.A. 2011. Ragam Jenis Ektoparasit dan Manajemen Penangkaran Biawak. [Skripsi]. Fakultas Kehutanan. Institut Pertanian Bogor. Bogor.

Rataj, A.V., Lindtner-Knific, R., Vlahović, K., Mavri, U., Dovč, A. 2011.Parasites in pet reptiles. Acta Vet. Scandinav., 53(1), 33.
Robbins, R.G. 1996. Does Aponomma varanensis (Acari: Ixodida: Ixodidae) occur on the Taiwanese mainland. J. Parasitol., 82, 672-673.

Setianingrum, A. 2010. Tungau Ektoparasit Pada Ular Micropechis ikaheka, Leiophyton albertisi dan Stegonotus sp. di Papua. [Skripsi]. Fakultas Matematika dan Ilmu Pengetahuan Alam Institut Pertanian Bogor, Bogor.

Stahlschmidt, Z., Brashears, J., DeNardo, D. 2011. The use of ultrasonography to assess reproductive investment and output in pythons. Biol. J. Linn. Soc., 103, 772-778.

Tanskul, P., Stark, H.E., Inlao, I. 1983. A checklist of ticks of Thailand (Acari: Metastigmata: Ixodoidea). J. Med. Entomol., 20(3), 330-341.

Telnoni, L. 2016. Prevalensi Infeksi Cacing Nematoda pada Ular Python reticulatus yang dipelihara Pecinta Ular di Denpasar. J. Vet., 5(2), 104-112.

Wall, R., Shearer, D. 2001. Veterinary Ectoparasites: Biology, Pathogy and Control. Blackwell Science Ltd.

Weber, M., Small, C. 2012. Amblyomma cajennense Animal Diversity https://animaldiversity.org/accounts/Amblyo $\underline{\text { mma_cajennense/ }}$

Widiastuti, D. 2008. Caplak, Tidak Hanya Membuat Gatal. Balaba: Jurnal Litbang Pengendalian Penyakit Bersumber Binatang Banjarnegara, 18-19. 